\title{
PENGARUH IKLIM ORGANISASI, KOMITMEN ORGANISASIONAL DAN KEPUASAN KERJA TERHADAP KINERJA KARYAWAN PADA PT. BPR KARANGWARU PRATAMA YOGYAKARTA
}

\author{
Nany Noor Kurniyati \\ Universitas Widya Mataram Yogyakarta \\ e-mail: nanykurniyati@gmail.com
}

\begin{abstract}
ABSTRAK
The objective of this research to know whether organizational climate organizational commitment and working satisfaction have the influence to employees performance. The research held in PT. BPR Karangwaru Pratama Mlati Sleman Yogyakarta. This research is quantitative by using method survey. Data collecting conducted through questionnaire and documentation. 45 employees determined as sampel in research or conceived of a census research. Technique analyse the data use the linear regression analysis and multiple linear regression. Result of research mention the organizational climate, komitmen organisasional and working satisfaction the employee own the positive and significant influence to employees performance at PT. BPR Karangwaru Pratama Yogyakarta. Level of influence of each variable that is organizational climate equal to $34,1 \%$, organizational commitment give the influence equal to $57 \%$ and working satisfaction give the influence equal to $18,8 \%$. Simultanly organizational climate, organizational commitment and working satisfaction own strong and significant influence to employee performance at PT. BPR Karangwaru Pratama Yogyakarta. This Matter is shown with the number of $R$ square equal to 0,571 and number of significant $F_{\text {counted }}$ equal to 18,189 larger ones from number $F_{\text {table }}$ equal to 2,88 at level 0,05.
\end{abstract}

Keywords: Organization Climate, Organization Commitment, Job Satisfaction, Job Performance

\section{PENDAHULUAN}

Dalam suatu organisasi sumber daya manusiamemegang perananutamadan memegang posisi kunci. Tuntutan terhadap pelayanan yang efektif, efisien dan inovatif, sangat terkait erat dengan perubahan peran dari fungsi sumber daya manusia dalam hal mengelola sumber daya manusia. Sumberdaya manusia dalam organisasi merupakan aspek krusial yang menentukan keefektifan sebuah perusahaan, karena perannya sebagai subyek pelaksana kebijakan dan kegiatan operasional perusahaan. Agar perusahaan tetap eksis maka harus berani menghadapi tantangan dan implikasinya yaitu menghadapi perubahan dan memenangkan persaingan. Mengingat pentingnya peran pengembangan SDM dalam perusahaan agar tetap dapat survive dalam iklim persaingan bebas, untuk itu perusahaan harus melakukan langkah-langkah manajerial yang tepat.

Persaingan bisnis perbankan saat ini semakin ketat. Perbankan adalah lembaga 
keuangan yang berperan sebagai financial intermediary. Meningkatnya persaingan tersebut ditandai dengan banyaknya jumlah bank dan bervariasinya persaingan produk atau jasa yang ditawarkan, salah satunya adalah Bank Perkreditan Rakyat (BPR). Bank Perkreditan Rakyat sebagai salah satu bank yang melaksanakan kegiatan usaha secara konvensional atau berdasarkan prinsip syariah yang dalam kegiatannya tidak memberikan jasa dalam lalu lintas pembayaran (Dendawijaya, 2005:5). Fungsi dari bank sebagai lembaga keuangan adalah lembaga yang membantu melancarkan pertukaran barangbarang dan jasa-jasa dan menyalurkan tabungan investasi.

Tuntutan profesionalisme pegawai dalam melaksanakan kerja di perusahaan saat ini yang dihadapkankepadamasalahbagaimanaperusahaan dapat menghadapi persaingan bisnis sehingga tetap eksis. Oleh karena itu diperlukan kesiapan bagi manajemen perusahaan agar dapat dicapai kinerja yang baik. Kinerja karyawanmenjadi sangat penting untuk ditingkatkan, terabaikannya unsur profesionalisme dalam menjalankan tugas dan fungsi perusahaan akan berdampak kepada menurunnya kinerja perusahaan.

Kinerja karyawan secara langsung maupun tidak langsung dapat dipengaruhi oleh beberapa faktor diantaranya iklim organisasi yang kondusif, Grant, et al, (2001) menyebutkan iklim organisasi yang sehat akan mampu mendorong sikap keterbukaan baik dari pihak karyawan maupun pihak pengusaha sehingga mampu menumbuhkan motivasi kerja yang searah antara karyawan dengan pengusaha dalam rangka menciptakan ketentraman kerja dan kelangsungan usaha kearah peningkatan produksi dan produktivitas kerja. Komitmen organisasional juga dianggap penting bagi perusahaan karena berpengaruh terhadap turnover karyawan. Terkait dengan kinerja, karyawan yang mempunyai komitmen terhadap perusahaan cenderung mengembangkan upaya yang lebih besar pada perusahaan. Sumber daya manusia dalam hal ini adalah para pegawai pada sebuah organisasi, tentunya berusaha bekerja dengan kemampuan yang mereka miliki agar dapat mencapai kepuasan kerja yang diinginkan. Semakin banyak aspek-aspek dalam pekerjaan yang sesuai dengan keinginan karyawan, semakin tinggi tingkat kepuasan yang dirasakannya (Moh. As'ad, 2003 : 104).

Ketiga faktor tersebut yaitu iklim organisasi, komitmen organisasional dan kepuasan kerja cenderung berpengaruh terhadap kinerja karyawan pada PT. BPR Karangwaru Pratama Pratama Yogyakarta. Berdasarkan latar belakang di atas maka permasalahan yang hendak dikaji dalam penelitian ini dapat dirumuskan sebagai berikut: (1) Apakah iklim organisasi mempunyai pengaruh terhadap kinerja karyawan pada PT. BPR Karangwaru Pratama Yogyakarta?; (2) Apakah komitmen organisasional karyawan mempunyai pengaruh terhadap kinerja karyawan pada PT. BPR Karangwaru Pratama Yogyakarta?; (3) Apakah kepuasan kerja karyawan mempunyai pengaruh terhadap kinerja karyawan pada PT. BPR Karangwaru Pratama Yogyakarta?.

\section{REVIEW LITERATUR DAN HIPOTESIS}

\section{Konsep Kinerja}

Anwar (2001: 67) mengatakan, bahwa istilah kinerja berasal dari kata "job performance" atau "actual performance" yaitu unjuk kerja atau prestasi sesungguhnya yang dicapai oleh seseorang dalam melaksanakan tugas sesuai dengan tanggung jawab yang diberikan kepadanya. Rivai (2006: 309) mengatakan bahwa kinerja merupakan perilaku nyata yang ditampilkan setiap orang sebagai prestasi kerja yang dihasilkan oleh karyawan sesuai dengan perannya dalam perusahaan. Selanjutnya Robbins (2001: 187) mendefinisikan bahwa kinerja sebagai sinergis dari beberapa unsur yaitu motivasi, kemampuan dan kesempatan. Mahsum 
(2006: 25) mendefinisikan bahwa kinerja adalah gambaran mengenai tingkat pencapaian pelaksanaan suatu kegiatan/program/kebijakan dalam mewujudkan sasaran, tujuan, misi dan visi organisasi yang tertuang dalam startegic planning suatu organisasi.

Selanjutnya, untuk mengukur kinerja pegawai, Dharma (2003: 355) mengatakan hampir semua cara pengukuran kinerja mempertimbangkan hal-hal sebagai berikut :

a. Kuantitas, yaitu jumlah yang harus diselesaikan atau dicapai. Pengukuran kuantitatif melibatkan perhitungan keluaran dari proses atau pelaksanaan kegiatan. Ini berkaitan dengan jumlah keluaran yang dihasilkan.

b. Kualitas, yaitu mutu yang harus dihasilkan (baik tidaknya). Pengukuran kualitatif keluaran mencerminkan pengukuran "tingkat kepuasan", yaitu seberapa baik penyelesaiannya. Ini berkaitan dengan bentuk keluaran.

c. Ketepatan waktu, yaitu sesuai tidaknya dengan waktu yang direncanakan. Pengukuran ketepatan waktu merupakan jenis khusus dari pengukuran kuantitatif yang menentukan ketepatan waktu penyelesaian suatu kegiatan.

\section{Iklim Organisasi}

Iklim organisasi juga merupakan faktor penting yang menentukan kehidupan suatu organisasi. Seperti yang dikemukan oleh Gibson et. all (2000: 34) bahwa iklim organisasi adalah sifat lingkungan kerja atau lingkungan psikologis dalam organisasi yang dirasakan oleh para pekerja atau anggota organisasi dan dianggap dapat mempengaruhi sikap dan perilaku pekerja terhadap pekerjaanya. Seperti dikatakan oleh Amundson dalam Martini dan Rostiana, (2003: 72) bahwa iklim organisasi mencerminkan kondisi internal suatu organisasi karena iklim hanya dapat dirasakan oleh anggota organisasi tersebut, dan iklim dapat menjadi sarana untuk mencari penyebab perilaku negatif yang muncul pada karyawan.

Iklim organisasi memiliki beberapa dimensi. Davis dan Newstrom (2004: 24) menyebutkan dimensi-dimensi yang tercakup dalam iklim organisasi meliputi: Kualitas kepemimpinan, Kepercayaan, Komunikasi, Perasaan melakukan pekerjaan yang bermanfaat, Tanggung jawab, Imbalan yang adil, Tekanan pekerjaan, Kesempatan, Pengendalian terhadap perilaku, Stuktur dan birokrasi, dan Partisipasi karyawan.

Dari beberapa pendapat ahli tersebut di atas, maka dapat dikatakan bahwa iklim organisasi adalah suasana yang diciptakan oleh hubungan antar individu yang berlaku dalam sebuah organisasi. Iklim organisasi juga merupakan keadaan di tempat kerja baik fisik maupun non fisik yang mendukung pelaksanaan tugas dalam organisasi dengan indikator kelengkapan sarana kerja, kenyamanan ruang kerja, adanya kejelasan tugas, hubungan yang baik dengan atasan dan rekan kerja, serta sistem penghargaan dan sanksi yang adil.

\section{Komitmen Organisasi}

Mahis dan Jackson (2000) dalam Sopiah (2008: 155) memberikan definisi, "Organizational Commitment is the degree to which employees believe in and accept organizational goals and desire to remain with the organization". Menurut Mowday (1982) dalam Sopiah (2008: 155) komitmen kerja sebagai istilah lain dari komitmen organisasional. Komitmen organisasional merupakan dimensi perilaku penting yang dapat digunakan untuk menilai kecenderungan karyawan untuk bertahan sebagai anggota organisasi. Komitmen organisasional merupakan identifikasi dan keterlibatan seseorang yang relatif kuat terhadap organisasi. Sedangkan menurut Lincoln (1994) dalam Sopiah, (2008: 155) komitmen organisasional mencakup kebanggaan anggota, kesetiaan anggota, dan kemauan anggota pada 
organisasi. Selanjutnya menurut Blau dan Boal (1995) dalam Sopiah, (2008: 155) komitmen organisasional didifinisikan sebagai suatu sikap yang merefleksikan perasaan suka atau tidak suka dari karyawan terhadap organisasi.

Indikator-indikator yang dapat digunakan untuk mengukur komitmen organisasional menurut Mowday dalam Sopiah (2008 : 165) antara lain:

1) Penerimaan terhadap tujuan organisasi,

2) Keinginan untuk bekerja keras,

3) Hasrat untuk bertahan menjadi bagian dari organisasi.

\section{Kepuasan Kerja}

Kepuasan kerja adalah sikap emosional yang menyenangkan dan mencintai pekerjaannya (Hasibuan, 2001: 202). Sedangkan menurut pendapat lain kepuasan kerja adalah tingkat kesenangan yang dirasakan seseorang atas peranan atau pekerjaannya dalam organisasi (Steers dalam Zuliyanti, 2005: 30). Menurut Handoko (dalam Zuliyanti, 2005: 30) kepuasan kerja suatu keadaan emosional yang menyenangkan dan tidak menyenangkan dimata karyawan memandang pekerjaan mereka. Kepuasan kerja mencerminkan perasaan seseorang terhadap pekerjaan mereka.

Kepuasan kerja akan didapat apabila ada kesesuaian antara harapan pekerja dan kenyataan yang didapatkan ditempat kerja. Selanjutnya, kepuasan kerja As'ad (2003: 65) dapat diukur berdasarkan persepsi/ tanggapan terhadap indikator sebagai berikut:

1) Aspek psikologik yang meliputi: minat, ketenteraman dalam kerja, sikap terhadap kerja, bakat dan ketrampilan.

2) Aspek sosial yang meliputi: hubungan antar karyawan, hubungan dengan atasan, hubungan dengan karyawan yang berbeda jenis pekerjaan, kesempatan berekreasi dan kegiatan perserikatan pekerja.

3) Aspek fisik yang meliputi: pengaturan waktu kerja dan waktu istirahat, perlengkapan kerja, keadaan ruangan, suhu, penerangan, pertukaran udara, kondisi kesehatan karyawan, umur, dan sebagainya.

4) Aspek finansial yang meliputi: sistem dan besarnya gaji, jaminan sosial, tunjangan, fasilitas yang diberikan dan promosi.

Penelitian tentang kinerja karyawan telah banyak dilakukan oleh beberapa peneliti. Beberapa hasil studi (Risher, 2002) menunjukkan tingkat gaji pokok tidak selalu dianggap penting oleh para pegawai. Para pegawai menginginkan manajemen dapat menghargai upaya-upaya yang telah mereka lakukan untuk kemajuan organisasi. Mengacu pendapat Risher ini, iklim organisasi sangat penting untuk diperhatikan agar kinerja pegawai dapat meningkat, misalnya dalam kejelasan uraian tugas dan batasan ukuran kinerja yang jelas.

Penelitian Vivi dan Rorlen (2007) berjudul pengaruh iklim organisasi dan kedewasaan terhadap kinerja karyawan pada PT. Graha Tungki Arsitektika Jakarta (BUMD) menunjukkan hasil bahwa iklim organisasi pada PT. Graha Tungki Arsitektika berpengaruh secara signifikan terhadap kinerja karyawan. Hal ini ditunjukkan oleh perolehan nilai koefesien regresi yang menunjukkan pola pengaruh positif antara iklim organisasi dan kinerja karyawan, dan dari nilai uji t yang menunjukkan Ho ditolak.

Penelitian yang dilakukan oleh Temitope (2010) berjudul Organizational Climate As a Predictor of Job Satisfaction and Commitment in Public Organizations menunjukkan hasil bahwa iklim Organisasi tidak memiliki pengaruh yang signifikan pada kepuasan kerja dan komitmen organisasi. Hasil penelitian yang diperoleh hanya membuktikan adanya pengaruh yang signifikan dari kepuasan kerja terhadap komitmen organisasi.

Penelitian juga dilakukan oleh Koesmono (2005) berjudul "Pengaruh Budaya Organisasi Terhadap Motivasi Dan Kepuasan Kerja Serta Kinerja Karyawan Pada Sub Sektor 
Industri Pengolahan Kayu Skala Menengah Di Jawa Timur". Hasil penelitiannya menunjukkan bahwa budaya organisasi berpengaruh terhadap motivasi dan kepuasan kerja serta kinerja pada karyawan industri pengolahan kayu skala menengah di Jawa Timur dapat diterima. Keempat variabel tersebut merupakan faktorfaktor dalam perilaku organisasi yang harus mendapatkan perhatian khusus bagi semua pihak yang terkait dengan proses produksi.

Selanjutnya penelitian yang menmbahas tentang kinerja juga dilakukan oleh Ketelaar dan Manning (2007) berjudul "Performancebased Arrangements for Senior Civil Servants OECD and other Country Experience". Hasil penelitiannya menyatakan bahwa untuk menciptakan kinerja aparatur yang maksimal, beberapa langkah yang perlu dilakukan adalah: 1) memilih staf yang sesuai dengan bidang kerjanya, 2) memberikan motivasi dan promosi kepada aparatur yang sudah senior, 3) menetapkan spesifikasi pekerjaan dalam periode waktu tertentu dan memberikan kriteria pencapaian kerja dan target yang akan dicapai.

\section{Hipotesis}

Berdasarkan dari latar belakang dan penelitian terdahulu, dapat disusun hipotesis dalam penelitian ini sebagai berikut:

H1: Iklim organisasi berpengaruh positif terhadap kinerja karyawan pada PT. BPR Karangwaru Pratama Yogyakarta

H2: Komitmen organisasional karyawan berpengaruh positif terhadap kinerja karyawan pada PT. BPR Karangwaru Pratama Yogyakarta

H3: Kepuasan kerja karyawan berpengaruh positif terhadap kinerja karyawan pada PT. BPR Karangwaru Pratama Yogyakarta

\section{METODE PENELITIAN}

Penelitian dilaksanakan di PT. BPR Karangwaru Pratama Mlati Sleman Yogyakarta.
Jenis penelitian ini adalah kuantitatif, dimana dalam penelitian ini menekankan pada pengujian teori-teori melalui pengukuran variabel penelitian dengan angka yang bertujuan menguji hipotesis. Selanjutnya, metode yang digunakan dalam penelitian ini adalah metode survey. Pengumpulan data dilakukan melalui kuesioner dan dokumentasi. Uji instrumen penelitian menggunakan uji validitas dan uji reliabilitas. Populasi dalam penelitian ini adalah seluruh karyawan PT. BPR Karangwaru Pratama. Dalam penelitian ini, seluruh populasi sebanyak 45 orang karyawan dijadikan sampel dalam penelitian atau disebut sebagai penelitian sensus. Teknik analisis data menggunakan analisis regresi linier sederhana dan regresi linier berganda. Pengujian asumsi klasik yang akan digunakan meliputi uji normalitas data, multikolinieritas dan heteroskedastisitas.

\section{HASIL PENELITIAN DAN PEMBAHASAN}

Kinerja seorang pegawai dapat diukur baik secara individu, kelompok maupun organisasi. Tinggi rendahnya kinerja individu, kelompok maupun organisasi dapat dilihat dari kuantitas dan kualitas pencapaian tugas-tugasnya, aspek kualitas mengacu pada beban kerja yang ditetapkan menjadi tanggung jawabnya, sedangkan kualitas kerja dapat dilihat dari rapi atau tidaknya pekerjaan yang dihasilkannya. Kinerja seorang pegawai berkaitan erat dengan kinerja organisasi dimana pegawai tersebut bekerja. Artinya apabila kinerja para pegawai tinggi maka kinerja organisasi juga akan tinggi. Dengan demikian, dalam upaya membangun kinerja organisasi hendaknya menjangkau keseluruhan unsur-unsur dari organisasi, termasuk strategi perencanaan pengembangan sumber daya manusianya.

Kinerja organisasi terkait dengan kondisi dinamis dari individu, kelompok, atau kelompokkelompok didalam organisasi yang tercermin dari ciri-ciri individu didalam melaksanakan 
tugas tanggungjawabnya, yang diterjemahkan melalui tingkat motivasi kerja yang diperlihatkan, sikap kerja, kemampuan kerja dan pengalaman kerja yang berkolaborasi dengan prosedur, tata cara dan hubungan kerja didalam organisasi yang diterjemahkan dalam proses kerja dalam bentuk administrasi dan manajemen, hasil kerja berupa barang atau jasa. Kinerja individu (individual performance) terbentuk dari, sikap kemampuan dan pengalaman kerja dari masingmasing pegawai. Sedangkan kinerja kolektif (coorporate performance) terbentuk dari kinerja dari keseluruhan pegawai yang ada didalam organisasi. Penelitian tentang kinerja pegawai merupakan suatu metode pendekatan manajerial untuk mengukur tingkat kinerja pegawai dalam menyelesaikan tugas tanggungjawabnya serta faktor-faktor yang berpengaruh terhadap kinerja. Kinerja tentu dipengaruhi oleh berbagai faktor, seperti iklim organisasi, komitmen pegawai dan kepuasan kerja pegawai.

\section{Tabel 1}

Ringkasan Hasil Pengujian Hipotesis Penelitian

\begin{tabular}{|c|l|c|c|c|c|}
\hline Hipotesis & $\begin{array}{c}\text { Deskripsi } \\
\text { Hubungan }\end{array}$ & $\mathrm{B}$ & $\begin{array}{c}\mathrm{t} \\
\text { hitung }\end{array}$ & Sig & Hasil \\
\hline H1 & $\begin{array}{l}\text { Iklim Organisasi } \\
\text { à Kinerja } \\
\text { Pegawai }\end{array}$ & 0,365 & 4,718 & 0,000 & $\begin{array}{c}\text { Berpengaruh } \\
\text { positif }\end{array}$ \\
\hline H2 & $\begin{array}{l}\text { Komitmen } \\
\text { Organisasi à } \\
\text { Kinerja Pegawai }\end{array}$ & 0,807 & 7,545 & 0,000 & $\begin{array}{c}\text { Berpengaruh } \\
\text { positif }\end{array}$ \\
\hline H3 & $\begin{array}{l}\text { Kepuasan } \\
\text { Kerja à Kinerja } \\
\text { Pegawai }\end{array}$ & 0,383 & 3,153 & 0,003 & $\begin{array}{c}\text { Berpengaruh } \\
\text { positif }\end{array}$ \\
\hline
\end{tabular}

Sumber: Data diolah

Berdasarkan ringkasan hasil pengujian hipotesis pada tabel 1, hasil hipotesis I dalam penelitian ini menunjukkan bahwa iklim organisasi memiliki pengaruh positif dan signifikan terhadap kinerja pegawai. Pengolahan data terhadap kekuatan pengaruh parsial iklim organisasi dalam mengestimasi kinerja pegawai, dilakukan dengan menggunakan uji-t statistik dimaksudkan untuk menguji signifikansi pengaruh secara parsial antara variabel bebas terhadap variabel terikat. Hasil pengolahan data seperti ditunjukkan tabel di atas menunjukkan angka $t_{\text {hitung }}$ sebesar 4,718 sedangkan nilai $t_{\text {tabel }}$ pada taraf kepercayaan $95 \%$ adalah sebesar 1,671 .

Berdasarkan uji signifikansi koefisien korelasi dengan menggunakan uji $\mathrm{t}$ diperoleh bahwa $t_{\text {hitung }}$ lebih besar $t_{\text {tabel, }}$ menunjukkan ada pengaruh secara signifikan antara iklim organisasi $\left(\mathrm{X}_{1}\right)$ terhadap kinerja pegawai $(\mathrm{Y})$. Dengan kata lain dapat dikatakan bahwa iklim organisasi memiliki pengaruh positif yang signifikan di dalam mengestimasi kinerja pegawai PT. BPR Karangwaru Pratama Yogyakarta.

Banyak peneliti yang melakukan penelitian tentang iklim organisasi telah bersepakat bahwa iklim organisasi adalah suatu yang bersifat psikologis, multidimensi, penomena yang kompleks yang mempunyai efek terhadap pembelajaran, kinerja, turnover, keabsenan dan jabatan yang tetap. Menurut Alavi dan Jahandari (2005: 249) bahwa faktor-faktor terpenting yang dapat mempengaruhi iklim organisasi adalah moral, kepemimpinan (leadership), organisasi formal dan informal dan keperibadian (personality).

Iklim organisasi memperhatikan penilaian atau tanggapan karyawan mengenai pentingnya aspek-aspek hubungan kerja dalam membentuk nilai-nilai organisasi Lippit et.al dalam Wei dan Morgan (2004: 378). Iklim organisasi telah mempertunjukkan pengaruh yang kuat terhadap tingkah laku individu dan kelompok di dalam organisasi. Elemen-elemen seperti sikap, nilainilai serta motif-motif yang dimiliki seorang individu mempunyai peranan penting dalam proses konseptual iklim organisasi. Selain itu, iklim organisasi dirasakan sebagai suatu yang bermanfaat bagi kebutuhan individu, misalnya iklim yang memperhatikan kepentingan pegawai, hubungan antar pegawai yaitu adanya hubungan yang harmonis dan berorientasi pada prestasi, maka dengan demikian dapat diharapkan bahwa tingkat perilaku pegawai atau pegawai yang 
mengarah pada tujuan kebutuhan dan motivasi pribadi itu tinggi. Dari pendapat-pendapat tersebut dapat diperoleh anggapan bahwa iklim organisasi merupakan salah satu faktor penting dalam peningkatan kinerja pegawai pada PT. BPR Karangwaru Pratama Yogyakarta.

Hasil penelitian pada pengujian hipotesis II dalam penelitian ini menunjukkan bahwa komitmen organisasional memiliki pengaruh positif dan signifikan terhadap kinerja pegawai. Berdasarkan uji signifikansi koefisien korelasi dengan menggunakan uji $\mathrm{t}$ diperoleh $\mathrm{t}_{\text {tabel }}=$ 1,671 dan $t_{\text {hitung }}=7,545$ sehingga diketahui bahwa $t_{\text {hitung }}$ lebih besar $t_{\text {tabel, }}$ menunjukkan ada pengaruh secara signifikan antara komitmen organisasional $\left(\mathrm{X}_{2}\right)$ terhadap kinerja pegawai (Y). Dengan kata lain dapat dikatakan bahwa komitmen organisasional memiliki pengaruh positif yang signifikan di dalam mengestimasi kinerja pegawai PT. BPR Karangwaru Pratama Yogyakarta.

Hasil penelitian ini sesuai dengan teori literatur maupun penelitian sebelumnya yang dilakukan oleh Ririn dan Mardiasmo (2004) dan Pangastuti (2008) yang menunjukkan bahwa komitmen organisasional berpengaruh terhadap kinerja pegawai. Memiliki komitmen organisasional merupakan elemen penting dalam bekerja di organisasi pemerintahan. Seseorang dengan memiliki komitmen organisasional di organisasi pemerintah dapat diharapkan memiliki pandangan yang positif serta berusaha berbuat yang terbaik untuk mencapai tujuan dan kinerja yang lebih baik lagi. Goal setting theory menyatakan bahwa individu berkomitmen terhadap sasaran, artinya bertekad untuk tidak menurunkan/meninggalkan sasaran atau menghasilkan tingkat kerja yang lebih tinggi.

Pendapat serupa juga dikemukakan oleh Mathieu dan Zajac (dalam Setiawan, 2005:39) bahwa dengan meningkatnya popularitas konsep komitmen organisasi didasarkan pada keyakinan bahwa komitmen organisasional memiliki implikasi bukan saja pada pegawai dan organisasi, namun juga pada masyarakat keseluruhan. Melalui upaya meningkatkan komitmen organisasi dapat menjadi salah satu cara guna meningkatkan untuk kepuasan karyawan dan akan berimplikasi pada kinerja. Organisasi yang mampu menumbuhkembangkan komitmen SDM yang dimiliki biasanya akan mampu mendayagunakan potensi kerja sumber daya yang dimiliki secara maksimum. Komitmen pegawai terhadap organisasi akan memungkinkan untuk menerima ganjaran ekstrinsik seperti penghasilan dan psikologis yang berhubungan dengan keanggotaan korp organisasi. Komitmen organisasi yang bagus diharapkan akan mengurangi perilaku terhadap penarikan diri, ketidakhadiran ataupun turnover karyawan.

Secarakonstruk, komitmenorganisasional dipandang sebagai konstruk unidimensi. Namun demikian, dalam perkembangannya berbagai fakta lanjutan menunjukkan bahwa individu mengembangkan komitmen organisasi melalui berbagai dimensi. Studi-studi awal yang dilakukan oleh Meyer dan Allen menunjukkan adanya sifat multidimensi dari konstruk komitmen organisasional Setiawan dan Ghozali (2005:39). Hal ini mengingatkan bahwa seluruh bentuk komitmen adalah tidak sama dan apabila organisasi bermaksud mempertahankan pegawainya dengan menguatkan level organisasional, maka eksistensi komitmen harus disadari adanya perbedaan bentuk-bentuk komitmen.

Hasil pengujian hipotesis III menunjukkan bahwa kepuasan kerja memiliki pengaruh positif dan signifikan terhadap kinerja pegawai. Berdasarkan uji signifikansi koefisien korelasi dengan menggunakan uji $\mathrm{t}$ diperoleh $\mathrm{t}_{\text {tabel }}=$ 1,671 dan $t_{\text {hitung }}=3,153$ sehingga diketahui bahwa $t_{\text {hitung }}$ lebih besar $t_{\text {tabel, }}$ menunjukkan ada pengaruh secara signifikan antara kepuasan kerja $\left(\mathrm{X}_{3}\right)$ terhadap kinerja pegawai $(\mathrm{Y})$. Dengan kata lain dapat dikatakan bahwa kepuasan kerja memiliki pengaruh positif yang signifikan di 
dalam mengestimasi kinerja pegawai PT. BPR Karangwaru Pratama Yogyakarta.

Hasil penelitian ini sejalan dengan pemikiran yang disampaikan oleh Luthans (2006: 246) yang menyatakan bahwa sekitar 20 tahun yang lalu, studi yang dinilai menurut meta-analisis mengindikasikan hubungan yang lemah (korelasi taksiran terdekat 0,17) antara kepuasan dan kinerja. Akan tetapi, analisis konseptual, metodologi empiris, dan praktis mempertanyakan dan memperdebatkan hasil yang lemah tersebut. Meta-analisis yang lebih rumit dilakukan oleh Tim Jugde dan rekannya pada 312 sampel dengan kombinasi N 54,417 menemukan korelasi sebenarnya menjadi 0,30 . Dengan demikian hasil analisis ini menunjukkan hubungan yang jauh lebih kuat antara kepuasan kerja dan kinerja karyawan.

Kaitan kepuasan kerja dengan kinerja karyawan juga dikemukakan oleh Dessler (2000) yang menyatakan bahwa kepuasan kerja antara lain mempunyai peran untuk mencapai produktivitas dan kualitas standar yang lebih baik, menghindari terjadinya kemungkinan membangun kekuatan kerja yang lebih stabil, serta penggunaan sumber daya manusia yang lebih efisien. Agar kepuasan kerja karyawan selalu konsisten maka setidaktidaknya perusahaan selalu memperhatikan lingkungan dimana karyawan melaksanakan tugasnya.

\section{KESIMPULAN DAN SARAN}

Berdasarkan analisis data dan pembahasan dapat diambil beberapa kesimpulan antara lain: Iklim organisasi memiliki pengaruh positif dan signifikan terhadap kinerja pegawai pada PT. BPR Karangwaru Pratama Yogyakarta. Hal ini ditunjukkan dengan angka signifikansi $t_{\text {hitung }}$ sebesar 4,718 yang lebih besar dari angka $t_{\text {tabel }}$ sebesar 1,671, pada level 0,05, sehingga pengaruh positif yang ditimbulkan antara iklim organisasi terhadap kinerja pegawai adalah signifikan.
Komitmen organisasional memiliki pengaruh positif dan signifikan terhadap kinerja pegawai pada PT. BPR Karangwaru Pratama Yogyakarta. Hal ini ditunjukkan dengan angka signifikansi $t_{\text {hitung }}$ sebesar 7,545 yang lebih besar dari angka $t_{\text {tabel }}$ sebesar 1,671, pada level 0,05, sehingga pengaruh positif yang ditimbulkan antara komitmen organisasional terhadap kinerja pegawai adalah signifikan.

Kepuasan kerja pegawai memiliki pengaruh positif dan signifikan terhadap kinerja pegawai pada PT. BPR Karangwaru Pratama Yogyakarta. Hal ini ditunjukkan dengan angka signifikansi $t_{\text {hitung }}$ sebesar 3,153 yang lebih besar dari angka $t_{\text {tabel }}$ sebesar 1,671, pada level 0,05, sehingga pengaruh yang ditimbulkan antara kepuasan kerja pegawai terhadap kinerja pegawai adalah signifikan.

Berdasarkan kesimpulan yang diperoleh dalam penelitian ini, dapat dikemukakan beberapa saran sebagai berikut: Upaya menciptakan iklim organisasi yang baik dapat dilakukan dengan memprioritaskan pembenahan melalui upaya meningkatkan kepercayaan kepada pimpinan, kemampuan pemimpin untuk melakukan komunikasi yang kondusif dengan para bawahan, melalui pengendalian terhadap perilaku kerja bagi para aparat, efektifitas dan efisiensi dalam penerapan struktur organisasi yang berlaku, serta memberdayakan seluruh pegawai dengan porsi kewenangan dan tanggungjawab yang jelas dalam perusahaan.

Melakukan upaya-upaya dalam menciptakan komitmen organisasional yang tinggi pada perusahaan melalui strategi pemberian pemahaman dan internalisasi kepada karyawan tentang visi, misi dan tujuan perusahaan, agar karyawan memiliki komitmen dan loyalitas tinggi, yang pada akhirnya akan berdampak kepada peningkatan kinerja pegawai.

Dari hasil penelitian ini berimplikasi bagi perusahaan untuk terus menerus menitikberatkan pada upaya penciptaan program 
promosi (karir) yang sesuai dengan harapan semua pihak. Perusahaan harus dapat mengoptimalkan program-program promosi dengan mengutamakan sumber daya manusia berasal dari dalam perusahaan, sehingga proses seleksi dan penarikan karyawan dari luar perusahaan diminimalisasi. Perusahaan juga harus mengembangkan fokus promosi (karir) melalui sistem promosi yang transparan, dan terukur secara jelas, Disamping itu, dukungan dari manajer sangat mempengaruhi kepuasan kerja yang dirasakan oleh karyawan. Dukungan lebih yang diberikan oleh manajer dapat membuat karyawan merasa nyaman dalam bekerja dan karyawan diberi tanggungjawab lebih sehingga karyawan dapat memaksimalkan kemampuannya untuk bekerja lebih baik.

\section{DAFTAR PUSTAKA}

Agus, Dwiyanto. 2005. Mewujudkan Good Governance Melalui Pelayanan Publik. Gajah Mada University Press, Yogyakarta.

Bankole Emmanuel Temitope. 2010. "Organizational Climate As A Predictor Of Job Satisfaction And Commitment In Public Organizations". Wilolud Journals, P.M.B 5363. Psychology Department, University of Ado Ekiti.

Bungin, Burhan. 2005. Metode Penelitian Kuantitatif. Kencana, Jakarta.

Davis, Keith, Newstrom. 2004. Perilaku Dalam Organisasi. Edisi Ketujuh. Erlangga, Jakarta.

Gibson, J.L., J.M. Ivancevich \& J. H. Donnelly. 2000. Organizations:Behavior, Structure and Processes. McGraw-HillCompanies, Inc., NewYork.
Hasibuan, Malayu S.P. 2005. Manajemen Sumber Daya Manusia. CV. Haji Masagung, Jakarta.

Hsiao WC. 2008. "When incentives and professionalism collide". Journal of Health Aff (Millwood. Vol 27 No. 4. Health Care Financing, Harvard School of Public Health, Massachusetts, USA. p 49-51.

Koesmono T. 2005. "Pengaruh Budaya Organisasi Terhadap Motivasi Dan Kepuasan Kerja Serta Kinerja Karyawan Pada Sub Sektor Industri Pengolahan Kayu Skala Menengah di Jawa Timur". Jurnal Manajemen dan Kewirausahaan, Vol. 7, No. 2, September 2005: 171-188.

Rostiana, Martini,Y. 2003. “Komitmen Organisasi ditinjau dari Iklim Organisasi dan Motivasi Berprestasi". Phronesis. Vol. 5. No. 9.p.21-31.

Saragih, Ferdinand D. 2006. "Menciptakan Pelayanan Publik yang Prima Melalui Metode Benchmarking Praktis". Jurnal Ilmu Administrasi dan Organisasi, Bisnis \& Birokrasi, Vol.14, No.3 (September).

Tirtarahardja, Umar dan S.L. La Sulo. 2005. Pengantar Pendidikan. Rineka Cipta, Jakarta

Umar, Husein. 2003. Metode Riset Perilaku Konsumen Jasa. Gholia Indonesia, Jakarta.

Vivi, Rorlen 2007. "Pengaruh Iklim Organisasi dan Kedewasaan Terhadap Kinerja Karyawan". Business \& Management Journal Bunda Mulia, Vol: 3, No. 1, Maret 2007PT. Graha Tungki Arsitektika Jakarta. Hal 51-59. 